\title{
Nostalgiese rit deur die verlede
}

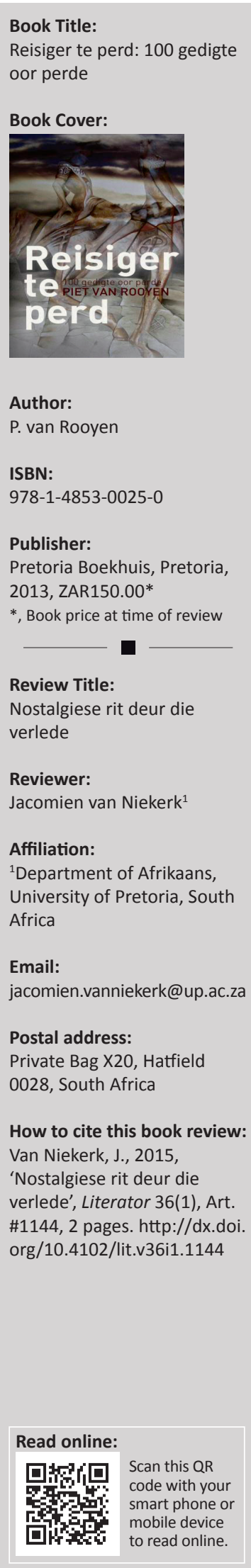

Die prosaskrywer en digter Piet van Rooyen is bekend vir die wyse waarop hy sy lewenservarings (byvoorbeeld die tyd wat hy saam met die San in Namibië deurgebring het) in sy kreatiewe werk inkorporeer. In Reisiger te perd kombineer Van Rooyen sy poësie met een van sy gunsteling tydverdrywe, naamlik perdry. Buiten sy kreatiewe werk is hy die outeur van Ten years of endurance riding in Namibia (2000) en hy het Namibiese nasionale kleure in hierdie sport verower.

Die konsep van 'n hele digbundel wat perde as tema het, herinner aan Johann Lodewyk Marais se bundel van 2002, Aves. In teenstelling tot die manier waarop die tema van voëls in Marais se bundel gestalte kry, handel Van Rooyen se bundel egter nie (primêr) oor verskillende perderasse of perdryaktiwiteite nie. Die gedigte in die bundel is eerder geïnspireer deur prosatekste uit die 'wêreldletterkunde' waarin perde ter sprake is. Soos die digter in die voorwoord tot die bundel verduidelik, het hy in sy 'leeswerk oor die jare die tekste aangestip wat oor perde handel en dit omgedig' (bl. 5) tot die gedigte in Reisiger te perd. Aan die einde van elke gedig word die outeur van die prosateks erken, en agterin die bundel is daar ' $n$ volledige bibliografie wat al die tekste lys waaruit Van Rooyen inspirasie geput het.

Die gevolg van Van Rooyen se werkwyse is dat hierdie bundel eweveel 'n bundel vir liefhebbers van die sogenaamde wêreldletterkunde is as vir perdeliefhebbers. Van Homeros tot Vergilius, van Leo Tolstoi tot Alexander Solzjenitsin en tot by Haruki Murakami en Kazuo Ishiguro dek die gedigte in die bundel ' $n$ wye verskeidenheid van gekanoniseerde skrywers en tekste. Hoewel Van Rooyen maan dat die leser nie 'n 'direkte vertaling' moet verwag nie, funksioneer die gedigte nogtans as interessante vertaaloefeninge (met die onvermydelike nadeel dat daar nie uit die oorspronklike tale vertaal is nie, maar uit Engels).

Van Rooyen se innoverende metode het egter tot gevolg dat dit moeilik is vir die gedigte om as gedigte bewondering af te dwing. In die oorgrote meerderheid van gedigte kom die prosabron te sterk deur en maak die gedigte die indruk van prosa wat in die vorm van versreëls afgedruk is. Die gedigte is nog steeds mooi letterkunde, maar eerder dan vertalings soos ek hierbo suggereer as die kreatiewe omdigtings waarna Van Rooyen gemik het. Dit blyk ook problematies dat Van Rooyen bloot in tientalle tekste gedeeltes onderstreep het waarin 'n perd of perde figureer, want die voorkoms van 'n perd in dié tekste is soms bloot toevallig en die subtitel waarin daar beweer word dat die bundel 'n honderd 'gedigte oor perde' bevat, is nie volkome akkuraat nie.

In die voorwoord word verder beweer dat die gedigte in volgorde van publikasie van die oorspronklike tekste gerangskik is, 'maar die idees bly tydloos'. Die idee dat literêre tekste 'tydloos' kan wees, is 'n aanvegbare perspektief wat ontken dat kanoniseringsprosesse ideologies van aard is. Die tekste wat Van Rooyen gekies het om te verwerk, illustreer trouens hoe tyden konteksgebonde die resepsie en interpretasie van letterkunde is. Hier dink ek aan die tekste waarin vroue met perde vergelyk word, soos in 'n gedig wat deur Charles Doughty ingegee is: 'wie 'n perd of 'n vrou besit/kan nooit behoorlik rus nie' (bl. 33), of aan Joseph Conrad se bekende rassisme wat op bladsy 40 deurskemer. Natuurlik is ons as moderne lesers goed geoefen om hierdie historiese kladmerke raak te sien en krities te evalueer, maar die klakkelose oorname van verouderde sienswyses sou myns insiens óók in die voorwoord gesinjaleer moes word.

Een van die prominentste insigte wat die leser uit Van Rooyen se keur uit die wêreldletterkunde wys word, is die feit dat perde 'n belangrike motief in 'n manswêreld is. Mans ry op 'n perd om hul geliefde te gaan besoek, of is 'n eensame cowboy, of maak oorlog met behulp van perde. Die oorkoepelende effek hiervan is dat die bundel gehul is in chauvinisme; die tema van perde is bloot 'n voorwendsel om oor ' $n$ wêreld te skryf waarin mans hul omgewing beheers. Vroue figureer slegs as die objek van begeerte ('vier van die mooistes' [bl. 22]; 'eendag op pad langs die meer' [bl. 31]; 'vrou wat in koets klim' [bl. 35]; 'volledige prentjie' [bl. 71]; ensovoorts), behalwe in die klein, klein handjievol gedigte gebaseer op tekste deur vroulike skrywers soos Karen Blixen en Copyright: (C) 2015. The Authors. Licensee: AOSIS OpenJournals. This work is licensed under the Creative Commons Attribution License. 
Virginia Woolf. Ek vind die gedig 'my donkerbruin merrie' (bl. 96) wat geïnspireer is deur die skrywer Colette een van die mees geslaagde tekste in die hele bundel.

In Reisiger te perd word daar op nostalgiese wyse teruggegryp na verbygegane eras en soos wat die digter liefderik deur die classics op sy boekrak blaai, vervaag daardie eras tot 'n eenvormige droom wat gerieflik sekere besonderhede ignoreer.

\section{Literatuurverwysings}

Marais, J.L., 2002, Aves, Protea Boekhuis, Pretoria.

Van Rooyen, P., 2000, Ten years of endurance riding in Namibia, Capital Press, Windhoek. 